\title{
Perancangan Sistem Informasi Persediaan Obat Berbasis Online Menggunagakan Framework Laravel Pada Apotek Sahabat
}

\author{
Afifa Ramadanty Wellete, Firman M.Pd, Matahari M.Kom \\ Universitas Pendidikan Muhammadiyah (UNIMUDA) Sorong \\ afifawellete28@gmail.com, firmantajdiduliman@gmail.com,mataharitarie@gmail.com
}

\begin{abstract}
Abstrak: Apotek Sahabat merupakan suatu usaha dagang yang bergerak dalam bidang penjualan obat yang dikaitkan dengan kepuasan customer. Dalam kegiatan pendataan obat, pencetakan laporan, dan segala kegiatan bisnis pada Apotek Sahabat masih dilakukan secara manual, sehingga apabila dilakukan pendataan obat akan membutuhkan waktu yang cukup lama. Ketersediaan obat di apotek merupakan kebutuhan utama bagi masyarakat yang sedang sakit, biasanya masyarakat yang berobat ke dokter akan diberikan resep obat yang selanjutnya masyarakat membeli sendiri obatnya di apotek. Tujuan penelitian ini adalah Menghasilkan website informasi persediaan obat apotek sahabat dan menghasilka buku panduan website informasi persediaan obat apotek sahabat. Bentuk penelitian ini menggunakan motode Research and Development (R\&D) dan menggunakan model Prototyping dalam pengembangan website. Berdasarkan hasil penelitian yang telah dilakukan di dapatkan hasil berupa Website Informasi Persediaan Obat Apotek Sahabat yang dapat berjalan dan petunjuk peggunaan sebagai pedoman penggunaan website yang keduanya telah melalui tahap ujicoba kepada 30 orang responden dengan memperoleh presentase nilai $91 \%$ untuk aspek pemograman, $78 \%$ untuk aspek tampilan dan 79\% untuk aspek pengguna. Dengan demikian dapat disimpulkan bahwa perancangan sistem informasi persediaan obat apotek sahabat dan petunjuk penggunaan website telah berhasil terselesaikan dan dapat di gunakan dengan baik serta memperoleh penilaian baik oleh pengguna.

Kata Kunci: Website; Persediaan; Obat; Sistem Informasi; Framework Laravel.
\end{abstract}

Abstract: Apotek Sahabat is a trading business that is engaged in the sale of drugs associated with customer satisfaction. In drug data collection activities, report printing, and all business activities at Apotek Sahabat are still carried out manually, so that if the drug data collection is carried out it will take quite a long time. Availability of drugs in pharmacies is a major need for people who are sick, usually people who go to the doctor will be given a drug prescription which then people buy their own medicine at the pharmacy. The purpose of this study is to produce a website for drug supply information for your pharmacy friends and produce a guide book for information about drug supply websites for your pharmacy friends. This form of research uses the Research and Development $(R \& D)$ method and uses the Prototyping model in website development. Based on the results of the research that has been done, the results are in the form of a website that can run on the Drug Inventory of Apotek Sahabat which can run and instructions for use as a guide to the use of the website, both of which have gone through the trial phase to 30 respondents by obtaining a percentage value of $91 \%$ for the programming aspect, $78 \%$ for the programming aspect. display and $79 \%$ for the user aspect. Thus, it can be concluded that the design of a drug supply information system for a friend's pharmacy and instructions for using the website has been successfully completed and can be used properly and has received good ratings by users.

Keywords: Website, Inventory, Medicine, Information System, Laravel Framework. 


\section{Pendahuluan}

Teknologi informasi saat ini telah berkembang sedemikian pesatnya, sehingga memaksa kita semua yang membutuhkan informasi aktual dan up to date untuk dapat menyesuaikan diri dengan perkembangan tersebut. Efisiensi penggunaan dan pemanfaatan teknologi komputer sudah sangat dirasakan sekali. Berbagai pengolahan data dilakukan secara komputerisasi, mulai dari penyimpanan data, arsip, membuat laporan, serta menghasilkan informasi, baik yang dibutuhkan secara perorangan maupun perusahaan. Komputer dapat memberikan informasi secara cepat dan tepat sekaligus dengan ketelitian yang sangat tinggi sekali terhadap setiap persoalan atau permasalahan yang dihadapi organisasi sesuai dengan sistem cepat dan akurat menjadi sangat esensial bagi sebuah organisasi baik yang bergerak dibidang komunikasi, komersial, kesehatan, militer, pendidikan, dan lain-lain. Perkembangan teknologi informasi dalam bidang kesehatan, yaitu dapat kita lihat pada suatu instansi kesehatan dalam mengolah data dengan hadirnya teknologi informasi (IT). Instansi kesehatan menggunakan teknologi komputer untuk mendapatkan informasi yang diperlukan dalam menyampaikan atau mengirim data dalam bentuk informasi. Untuk mendapatkan pelayanan dan informasi mengenai pemahaman kesehatan, diperlukan suatu tempat yang dapat digunakan untuk menyalurkan dan memberikan informasi obat-obatan yang lengkap kepada masyarakat, salah satunya adalah apotek.

Berdasarkan Peraturan Pemerintahan No.25 tahun 1980 dan Permenkes No.922/MenKes/X/1993, ${ }^{[1]}$ Apotek adalah suatu tempat tertentu dimana dilakukan pekerjaan kefarmasian dan penyaluran obat kepada masyarakat. Apotek dalam kesehariannya memiliki kewajiban untuk menyediakan, menyimpan, dan menyalurkan kebutuhan farmasi yang bermutu baik dan terjamin keabsahannya (resmi). Kebutuhan farmasi yang disalurkan oleh apotek meliputi obat, bahan obat, alat kesehatan, dan sebagainya ${ }^{[1]}$.

Pengelolaan obat terbagi menjadi 5 fungsi dasar yang dinamakan siklus Manajemen Sediaan Farmasi yang terdiri dari: perencanaan (selection), pengadaan (procurement), distribusi (distribution), dan penggunaan (user). Kesuksesan siklus manajemen ini bergantung pada kemampuan secara andal dan konsisten memasukan obat-obat yang berkualitas, sesuai standar, dengan harga yang terjangkau bagi seluruh tingkatan sistem perawatan kesehatan (Iqbal, Geer, \& Dar, 2016; Muhia Waithera, \& Songole, 2017).

Dalam jurnal yang berjudul "Analisi Dan Perancangan Sistem Informasi Stok Obat Pada Apotek Arjowinangun" dijelaskan bahwa proses yang ada diantaranya adalah pengolahan data obat, proses pengolahan data masih bersifat manual dan membutuhkan waktuyang sangat lama. Metode yang digunakan adalah interview(wawancara) langsung ke lapangan dan dengan mengumpulkan data-data yang akan digunakan dalam proses perancangan. Pengembangan sistem masih menggunakan metode terstruktur, yaitu $D F D, E E R$, dan ERD belum ada metode dengan menggunakan bahasa pemrograman Visual Basic (Mujiati, 2016).

Apotek Sahabat merupakan suatu usaha dagang yang bergerak dalam bidang penjualan obat. Apotek ini bertempat di Jln.Buncis Kelurahan Malawili, Distrik Aimas Unit 2, Kabupaten Sorong, yang memiliki ruang lingkup Instalasi Farmasi yang lebih kecil dibandingkan dengan rumah sakit pada umumnya. Obat yang ada di Apotek Sahabat terdiri dari berbagai jenis obat, antara lain adalah obat dengan resep, obat wajib apotek, obat generik berlogo, dan obat bebas. Obat-obatan tersebut secara keseluruhan jumlahnya sangat banyak sekitar 1000 jenis obat. Informasi tentang obat sangat penting untuk diketahui, terutama fungsi obat tersebut. Dalam kegiatan pendataan obat, pencetakan laporan, dan segala kegiatan bisnis pada Apotek Sahabat masih dilakukan secara manual, sehingga apabila dilakukan pendataan obat akan membutuhkan waktu yang cukup lama sehingga menghambat kinerja dari Apotek Sahabat. 
Permasalahan lain yang terjadi ada pada masyarakat, dimana ketersediaan obat di apotek merupakan kebutuhan utama bagi masyarakat yang sedang sakit, biasanya masyarakat yang berobat ke dokter akan diberikan resep obat yang selanjutnya masyarakat membeli sendiri obatnya di apotek. Kesulitan masyarakat yang terjadi adalah tidak adanya informasi mengenai obat yang tersedia di apotek dan dimana lokasi apotek itu berada, kebutuhan akan obat dalam waktu yang singkat dan mudah menjadi problema berkepanjangan di masyarakat. Untuk mengatasi hal tersebut, maka selayaknya dibuat suatu sistem pengolahan data persediaan obat dengan memanfaatkan perangkat lunak berbasis teknologi yang dapat membantu mewujudkan sistem informasi yang cepat, akurat dan dapat dipertanggungjawabkan.

Berdasarkan latar belakang diatas maka penulis tertarik untuk melakukan penelitian dengan judul "Perancangan Sistem Informasi Persediaan Obat Berbasis Online Menggunakan Framework Laravel Pada Apotek Sahabat", aplikasi ketersediaan obat yang dapat diakses dari mana saja dan kapan saja menggunakan smartphone. aplikasi ini dibuat dengan menggunakan web dimana terdapat menu-menu seperti menu pencarian obat yang dapat digunakan oleh masyarakat untuk melakukan proses pencarian obat pada apotek sahabat, selain itu ada menu update ketersediaan obat, menu input data obat, menu input ketersediaan obat dan menu input pemakaian obat yang bisa digunakan oleh pihak apotek dalam menginput data obat pada sistem.

Aplikasi tersebut diharapkan akan mempermudah masyarakat dalam mengecek ketersediaan obat yang dicari baik dari nama obat, jenis obat, stok obat, harga obat, bentuk obat dan lokasi apotek sahabat. Untuk mencapai tujuan tersebut penulis melakukan pendekatan dengan metode penelitian yaitu: pengamatan langsung, wawancara, kepustakaan, dan metode analisis serta perancangan sistem, sedangkan bahasa pemrograman yang digunakan adalah PHP dan database MySQL. Hasil dari perancangan sistem ini adalah menghasilkan sistem informasi Persediaan Obat yang meliputi pengelolaan input dan output data, sehingga tercapai tujuan dari tugas akhir untuk dapat mengatasi masalah yang ada dalam Apotek Sahabat.

\section{Metode Penelitian}

Dalam sebuah penelitian, sudah tentu harus memiliki langkah-langkah penelitian yang akan digunakan sebagai acuan penulis. Pada penelitian ini, peneliti menggunakan model penelitian Research and Development $(R \& D)$ atau Penelitian dan Pengembangan. Metode penelitian dan pengembangan atau dalam bahasa Inggrisnya Research and Development adalah metode penelitian yang digunakan untuk menghasilkan produk tertentu dan menguji keefektifan produk (Pangesti, 2019).

ADDIE berlandaskan behaviorisme, cetusan ide yang dikembangkan oleh Dick dan Carry (1996) untuk merancang sistem pembelajaran (Hermanto, S. Sudaryanto, C, Febriana, 2020). Istilah ADDIE merupakan satu akronim bagi Analysis (analisis), Design (reka bentuk), Development (pengembangan), Implementation (pelaksanaan), dan Evaluation (penilaian). Salah satu fungsi ADDIE yaitu untuk menjadi pedoman dalam membangun atau mengembangkan suatu perangkat dan berfungsi sebagai program pelatihan yang ersifat dinamis dan efektif.

\section{Hasil Dan Pembahasan}

Penelitian ini dilakukan pada bulan Juli 2021 s/d September 2021 di Apotek Sahabat, Jln.Buncis Kelurahan Malawele, Distrik Aimas Unit 2, Kabupaten Sorong.

Hasil penelitian yang disajikan dalam bab ini adalah hasil perancangan website informasi persediaan obat yang telah dilakukan terhadap karyawan apotek sahabat dan masyarakat kabuptaen sorong. 


\subsection{Hasil Penelitian}

Berikut ini merupakan paparan hasil perancangan sistem informasi persediaan obat berbasis online menggunakan framework Laravel.

Pengemabngan dan Penelitian dilakukan di Apotek Sahabat. Dalam penelitian tersebut, peneliti menghasilkan produk sistem informasi persediaan obat berbasis online menggunakan framework Laravel dengan menggunakan metode pengembangan ADDIE (Analyse, Design, Development, Implementation, and Evaluation) sebagai pedoman dalam proses pengembangan. Pada pembahasan sebelumnya, peneliti telah menjelaskan tahapan-tahapan proses pengembangan sistem informasi persediaan obat berbasis online menggunakan framework Laravel. Selanjutnya, pada pembahasan ini akan dijelaskan hasil dari pengembangan media yang telah diajukan kepada ahli media dan responden mengenai pengembangan sistem informasi persediaan obat berbasis online menggunakan framework laravel pada apotek sahabat. Tampilan sistem dapat dilihat pada Gambar 1.
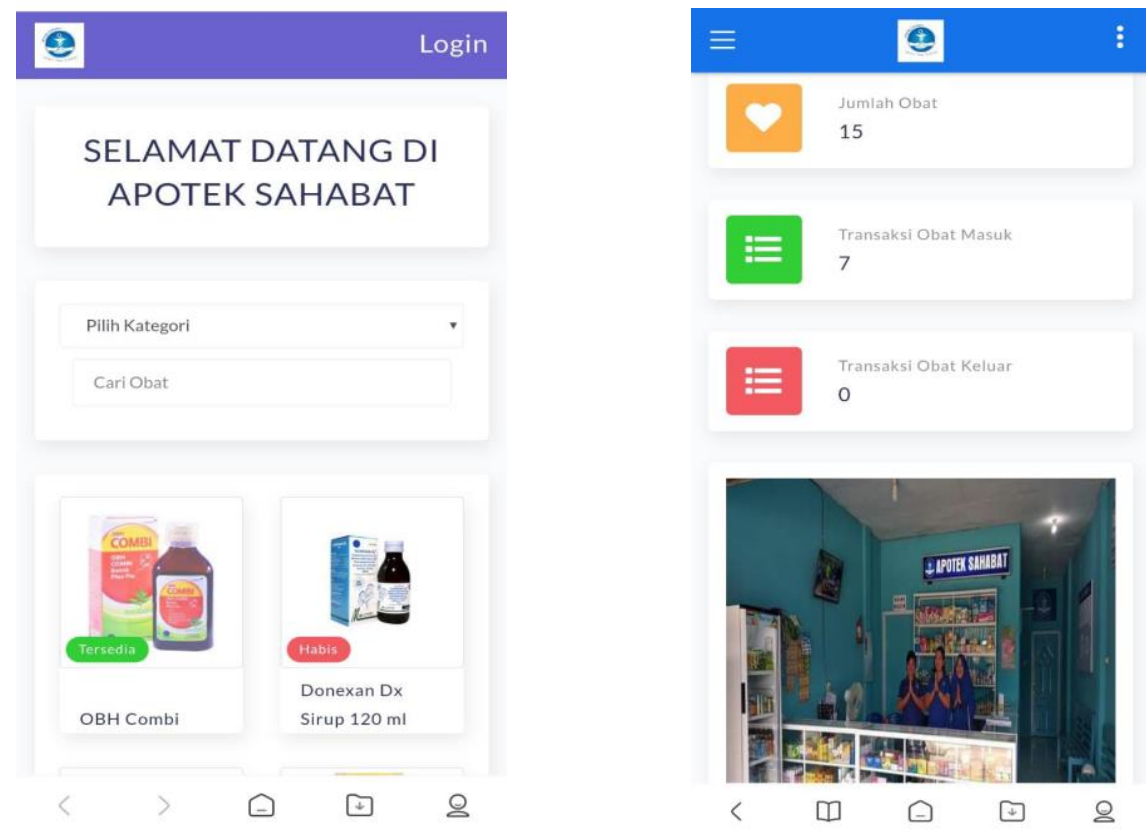

Gambar 1. Tampilan Hasil Perancangan Sistem

Adapun tahapan pengembangan media yang telah dilakukan berdasarkan model pengembangan ADDIE (Analyse, Design, Development, Implementation, and Evaluation).

\section{A. Analyze (Analisis)}

Tahapan persiapan awal dalam proses pengembangan sistem informasi persediaan obat yaitu analisis. Analis yang dilakukan peneliti mencakup dua hal, yaitu analisis masalah dan analisis kebutuhan. Analisis masalah bertujuan untuk mengidentifikasi waktu pengolahan data persediaan obat, serta mengidentifikasi hambatan pelaksanaan pencarian persediaan obat. Langkah yang dilakukan melalui observasi dan wawancara proses pengolahan dan pencarian stok obat pada apotek. Setelah melakukan observasi dan wawancara dari karyawan apotek, muncul permasalahan bahwa dalam kegiatan pendataan obat, pencetakan laporan, dan segala kegiatan bisnis pada Apotek 
Sahabat masih dilakukan secara manual, sehingga apabila dilakukan pendataan obat akan membutuhkan waktu yang cukup lama sehingga menghambat kinerja dari Apotek Sahabat.

B. Design (Desain)

Tahap ini mulai merancang pembuatan media evaluasi yang akan dikembangkan mengacu pada hasil analisis masalah dan analisis kebutuhan. Adapun tahapan perancangan media mmeliputi:

1) Menyusun konsep media evaluasi berbasis laravel.

Secara garis besar, deskripsi konsep media evaluasi sebagai berikut:

a. Jenis aplikasi : Media evaluasi informasi persediaan obat berbasin online menggunakan laravel.

b. Tujuan : Menerapkan informasi persediaan obat berbasis online yang praktis, efektif, dan efisien

c. Pengguna : Diharapkan dapat digunakan baik karyawan, maupun masyarakat.

d. Software : Laravel 8, Cpanel, dan Microsoft Office Word

e. Gambar dan Kalimat Panduan: Gambar diambil dari internet. Sedangkan kalimat panduan dibuat sendiri oleh penulis menggunakan Microsoft Office Word

f. Data Obat : diambil dari arsip apotek, kemudian diolah kedalam website

g. Development (Pengembangan)

C. Development (Pengembangan)

Setelah rancangan media evaluasi sudah terbentuk, tahap selanjutnya mewujudkan hasil rancangan, kemudian akan divalidasi oleh tim expert yaitu meliputi ahli media dan ahli materi.

\section{Implementation (Implementasi)}

Pengujian media dilaksanakan sesudah media direvisi. Hal ini sesuai dengan metode pengembangan ADDIE yang temasuk dalam tahapan implementasi media. Media diujikan kepada kelompok terbatas dan kelompok operasional pada karyawan dan masyarakat. Kelompok terbatas pada karyawan dan masyarakat terdiri dari 6 orang yang peneliti pilih menggunakan teknik acak.

E. Evaluation (Evaluasi)

Dalam penelitian ini dilaksanakan dua tahap evaluasi, yaitu evaluasi formatif dan evaluasi sumatif. Evaluasi formatif sudah dilakukan selama fase-fase sebelum produk diterapkan pada pembelajaran melalui angket penilaian ahli media yang digunakan untuk memperbaiki kembali media yang sudah dikembangkan sehingga layak untuk diterapkan dalam pelaksanaan evaluasi informasi informasi persediaan obat. Sedangkan evaluasi sumatif dilakukan setelah media diterapkan dengan tujuan untuk menilai kevalidan, kepraktisan, dan keefektifan.

\subsection{Pembahasan}

Ujicoba skala besar di lakukan kepada konsumen (masyarakat). dengan target responden berjumlah 24 orang yang bersedia melakukan ujicoba website sistem informasi persediaan obat apotek sahabat pada lembar kertas yang telah disebar langsung kepada masuarakt dan karyawan apotek sahabat. Ujicoba yang dilakukan akan mengukur 6 indikator yaitu (1) aspek kualitas aplikasi, (2) aspek navigasi, (3) penggunaan aplikasi praktis, (4) efektif, (5) kepuasan pengguna, (6) dampak bagi masyarakat dan apotek. Pengujian website dilakukan dengan mencoba seluruh proses input dan output serta melakukan percobaat terhadap seluruh fitur yang ada dalam website informasi persediaan obat apotek sahabat. Dalam ujicoba skala besar ini peneliti memperoleh 24 responden yang merupakan masyarakat dan karyawan apotek.. 
Tabel 1. Hasil Validasi

\begin{tabular}{|c|l|c|c|}
\hline No & $\begin{array}{l}\text { Komponen } \\
\text { atau } \\
\text { Indikator }\end{array}$ & Jumlah & $\begin{array}{c}\text { Skor } \\
\text { Maks }\end{array}$ \\
\hline 1 & $\begin{array}{l}\text { kualitas } \\
\text { aplikasi }\end{array}$ & 657 & 720 \\
\hline 2 & Navigasi & 536 & 600 \\
\hline 3 & $\begin{array}{l}\text { Penggunaan } \\
\text { aplikasi } \\
\text { praktis }\end{array}$ & 316 & 360 \\
\hline 4 & $\begin{array}{l}\text { Penggunaan } \\
\text { aplikasi } \\
\text { efektif }\end{array}$ & 321 & 360 \\
\hline 5 & $\begin{array}{l}\text { Kepuasan } \\
\text { pengguna }\end{array}$ & 106 & 120 \\
\hline 6 & $\begin{array}{l}\text { Dampak } \\
\text { bagi } \\
\text { masyarakat } \\
\text { dan apotek }\end{array}$ & 217 & 240 \\
\hline Keseluruhan Indikator & $\mathbf{2 1 5 3}$ & $\mathbf{2 4 0 0}$ \\
\hline
\end{tabular}

Kegiatan ini dilakukan untuk mengetahui sistem informasi persediaan obat apotek sahabat, tesis dapat berdaya guna bagi masyarakat dan apotek. Hasil uji coba kelompok kecil secara keseluruhan dapat dilihat pada lampiran 1 dimana uji coba ini dilakukan terhadap 23 masyarakat dan 1 karyawan apotek..

$$
\begin{aligned}
& \quad \text { Presentase Kelayakan }=\frac{\text { Nilai Total }}{\text { Nilai Maksimum }} \times 100 \% \\
& =\frac{2153}{2400} \times 100 \% \\
& =989 \%
\end{aligned}
$$

Penilaian uji coba kelompok besar kepada responden yang masing-masing diberi angket berisi aspek Kualitas aplikasi. Hasil penilaian responden dikategorikan sangan baik jika X> 80\% ; sangat baik, jika $X \leq 80 \%$; baik, jika $X \leq 60 \%$; cukup baik jika $X \leq 40 \%$; kyrang baik, dan jika $X \leq 20 \%$; sangat kurang baik .

Berdasarkan tabel 1 diketahui bahwa media yang dikembangkan ditinjau dari kelayakan aspek diperoleh presentase rata-rata yaitu 89\%yang termasuk ke dalam kriteria "Sangat Baik" dan dapat dikatakan bahwa kualitas aplikasi termasuk ke dalam kriteria "Sangat Layak".

\section{Kesimpulan Dan Saran}

Berdasarkan analisis data dan pembahasan sebelumnya, maka dapat disimpulkan bahwa: Kevalidan sistem informasi persediaan obat berbasis online menggunakan laravel ditinjau dari aspek-aspek berdasarkan hasil penilaian ahli media dalam rangkaian tahapan pengembangan 
secara keseluruhan termasuk dalam kriteria "Sangat Layak" dengan skor 91\% yang artinya media "Sangat Layak" untuk diuicobakan kepada responden. Panduan penggunaan sistem informasi persediaan obat berbasis online menggunakan laravel tercantum pada menu panduan dan book manual (buku panduan). Kepraktisan berdasarkan hasil responden terhadap sistem informasi persediaan obat berbasis online menggunakan laravel, penilaian ditinjau dari aspek-aspek secara keseluruhan termasuk kriteria "Sangat Praktis" dengan skor $87 \%$ yang artinya media sangat praktis untuk digunakan bagi responden. Sedangkan pada penilaian Keefesien berdasarkan hasil responden terhadap sistem informasi persediaan obat berbasis online menggunakan laravel, penilaian ditinjau dari aspek-aspek secara keseluruhan termasuk kriteria "Sangat Efektif" dengan skor $89 \%$ yang artinya media sangat efektif untuk digunakan bagi responden

Berdasarkan hasil penelitian, maka ada beberapa saran yang dapat digunakan sebagai bahan pertimbangan untuk menjadikan apa yang telah dikembangkan menjadi lebuh baik lagi, saran tersebut antara lain: Bagi peneliti berikutnya yang ingin mengembangkan aplikasi sistem informasi persediaan obat agar dapat membuat aplikasi berbasis android, dengan menambah berbagai fitur, seperti info kesehatan, dan pemesanan obat yang dapat digunakan oleh masyarakat. Perlu adanya pengembangan dan pemeliharaan yang lebih baik lagi terhadap sistem yang telah dibuat, sehingga sistem dapat dipergunakan sesuai dengan kebutuhan. Mempertahankan kinerja yang baik yang telah dicapai dan dilaksanakan oleh pihak apotek sahabat.

\section{Daftar Pustaka}

Astika, I. G. B. (2018). Sistem Informasi Eksekutif Pada Puskesmas Karangasem Menggunakan Framework Laravel.

Alakel, W., Ahmad, I., \& Santoso, E. B. (2019). Sistem Informasi Akuntansi Persediaan Obat Metode First In First Out (Studi Kasus: Rumah Sakit Bhayangkara Polda Lampung). Jurnal Tekno Kompak.

Badri, A. (2019). Perancangan Sistem Informasi Pengolahan Data Produksi Sawit Pada Pt. Tebo Plasma Inti Lestari (Pt. Tpil) Berbasis Web (Doctoral Dissertation, Stikom Dinamika Bangsa Jambi).

Dick and Carey (1996). The Systematic Dessign of Instuction, New York :Harper Collins Publishers.

Elisa, Febi Safitri, A. S. And K. S. S. (2019). Perancangan Aplikasi Ketersediaan Obat Pada Apotek Di Kota Medan Berbasis Android. Sensasi, 369-373.

Hermanto, H., Sudaryanto, S., \& Febriana, C. (2020). PENGEMBANGAN BUKU BERBASIS ENSIKLOPEDIA UNTUK MATA KULIAH BUDAYA INDONESIA PROGRAM DARMASISWA. Pena Literasi, 3(1), 20-28.

Iqbal, M. J., Geer, M. I., \& Dar, P. A. (2016). Medicines management in hospitals: A supply chain perspective. Systematic Reviews in Pharmacy, 8(1), 80-85. https://doi.org/10.5530/srp.2017.1.14.

Muhia, J., Waithera, L., \& Songole, R. (2017). Factors Affecting the Procurement of Pharmaceutical Drugs: A Case Study of Narok County Referral Hospital, Kenya. Medical \& Clinical Reviews, 03(04), 1-8. https://doi.org/10.21767/2471-299x.1000061 